\title{
Commentary: Early Diagenetic Imprint on Temperature Proxies in Holocene Corals: A Case Study From French Polynesia
}

\author{
Gilbert Camoin * and Nadine Hallmann \\ Aix-Marseille Université, CNRS, IRD, INRAE, Coll France, CEREGE, Europôle Méditerranéen de l'Arbois, Aix-en-Provence, \\ France
}

Keywords: sea-level, reef, microatoll, palaeoclimate, Holocene

\section{A Commentary on}

Early Diagenetic Imprint on Temperature Proxies in Holocene Corals: A Case Study From French Polynesia

by Rashid, R., Eisenhauer, A., Liebetrau, V., Fietzke, J., Böhm, F., Wall, M., et al. (2020). Front. Earth Sci. 8:301. doi: 10.3389/feart.2020.00301

\section{INTRODUCTION}

OPEN ACCESS

Edited by:

Oscar Branson,

University of Cambridge,

United Kingdom

Reviewed by:

Anne M. Gothmann,

St. Olaf College, United States

${ }^{*}$ Correspondence:

Gilbert Camoin

camoin@cerege.fr

Specialty section:

This article was submitted to

Biogeoscience,

a section of the journal

Frontiers in Earth Science

Received: 30 October 2020 Accepted: 09 April 2021

Published: 04 May 2021

Citation:

Camoin G and Hallmann N (2021) Commentary: Early Diagenetic Imprint

on Temperature Proxies in Holocene

Corals: A Case Study From French Polynesia. Front. Earth Sci. 9:623767.

doi: 10.3389/feart.2021.623767
Rashid et al. (2020) presented mid- to late-Holocene SST reconstructions obtained on fossil Porites corals from French Polynesia. They especially report centennial to millennial SST trends on the order of $\pm 2{ }^{\circ} \mathrm{C}$ and relate them to sea-level changes that were previously published by Rashid et al. (2014). The authors conclude that cyclic SST variations may superimpose Glacial Isostatic Adjustment (GIA)-controlled sea-level height.

\section{Subsections Relevant for the Subject}

The following discussion is focused on the paragraph 'Implications for the Sea Level and Temperature Relationships in the Pacific' and Figure 10 from Rashid et al. (2020).

\section{DISCUSSION}

During the mid- to late-Holocene, low-amplitude $(\sim 1 \mathrm{~m})$ relative sea-level $(\mathrm{RSL})$ changes were mostly governed by GIA processes (e.g., Camoin and Webster, 2015 and references therein). The reconstruction of RSL changes at high resolution requires the use of reliable sea-level indicators, including salt marsh microfossils, archaeological remains, vermetid constructions, and fossil corals. Among these indicators, coral microatolls represent unique archives of the mean low water springs (MLWS) level in open water settings.

The interpretation of the SST/sea-level relationship by Rashid et al. (2020) is based on a previously defined sea-level curve (Rashid et al., 2014), which includes only three coral microatolls from two islands. Furthermore, the relevant dataset is characterized by scattered data, with differences in elevation of up to $2 \mathrm{~m}$ for coeval corals from the same island. This indicates that the dated corals typify diverse palaeoenvironments and palaeowater depths and cannot be therefore regarded as accurate sea-level indicators to reconstruct the RSL changes at high resolution during that time window. Furthermore, such a reconstruction is additionally hampered by uncertainties related to elevation measurements that have been estimated to $\pm 0.4 \mathrm{~m}$ (Rashid et al., 2014). 


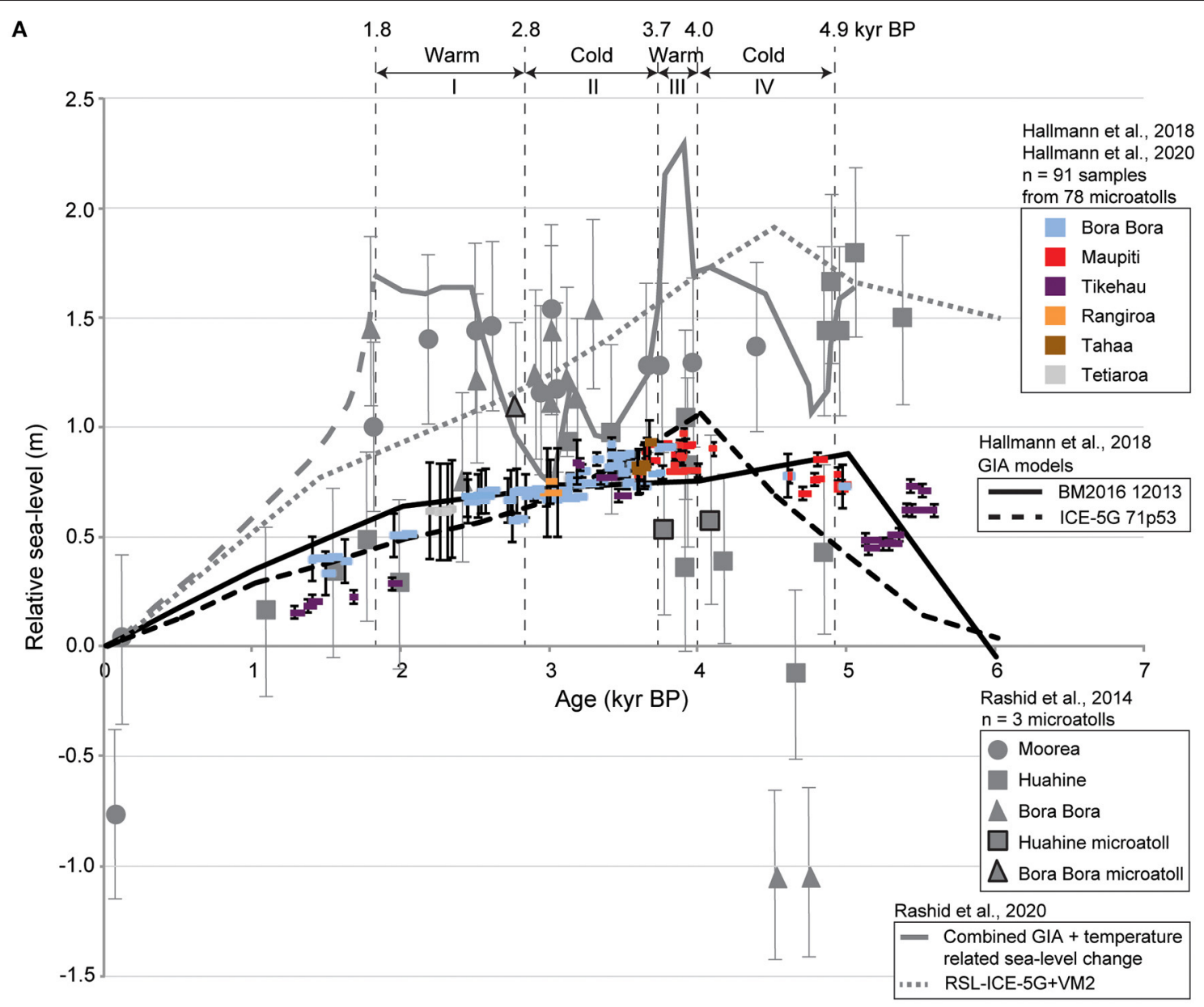

B

Age (kyr BP)

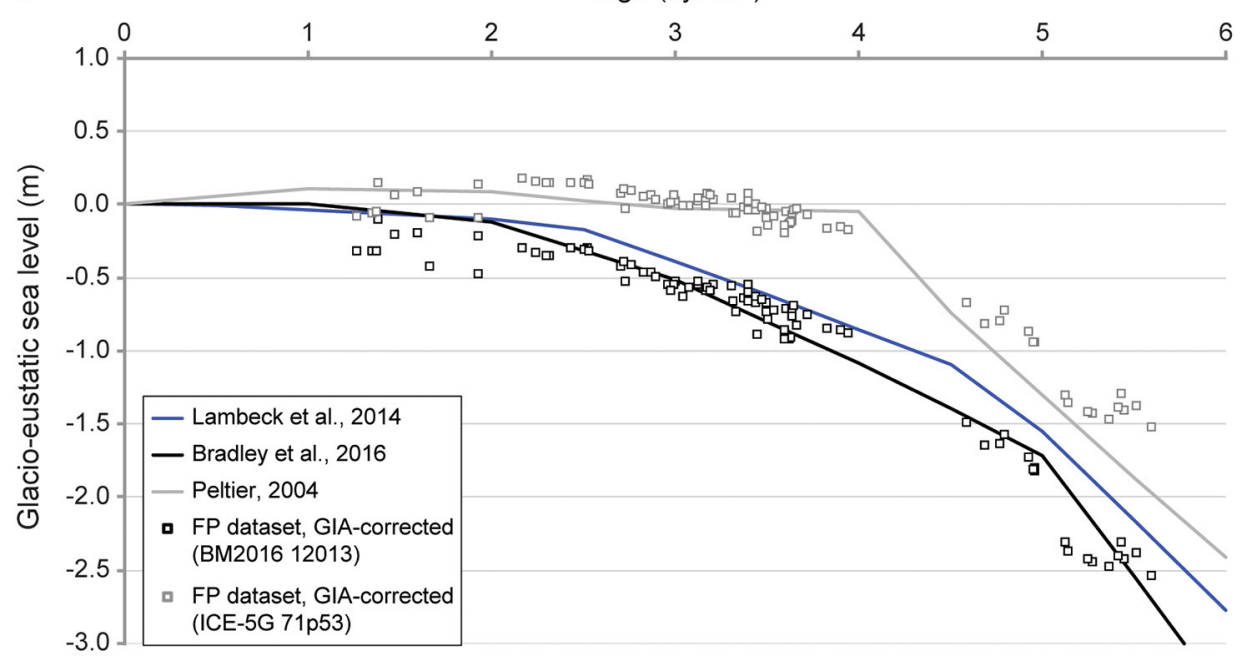

FIGURE 1 | (A) Reconstructed mid- to late-Holocene RSL changes in French Polynesia (Hallmann et al., 2018, 2020; in color) compared to model outputs based on BM2016 (black solid line) and ICE-5G ice models (black dashed line). This reconstruction overlies sea-level estimates from Rashid et al. (2014; in gray), their ICE-5G model output (gray dashed line) and the combined GIA-temperature related sea-level change presented in Rashid et al. (2020; gray solid line). For the Hallmann et al. $(2018,2020)$ dataset, the BM2016 model captures the older data better than ICE-5G as it produces an earlier highstand, however, the curve produced by ICE-5G better tracks the observations for the period after $4 \mathrm{kyr} \mathrm{BP}$. This is also reflected in the consistency between the model curves (black and gray lines) and the model-corrected data (black and gray boxes) in (B). In contrast to the 1-m sea-level highstand revealed by Hallmann et al. (2018, 2020), the ICE-5G model by Rashid et al. (2014) results in a $2 \mathrm{~m}$ sea-level highstand. However, the Rashid et al. (2014) dataset is scattered and only one microatoll from Bora Bora is consistent with the 
FIGURE 1 | Rashid et al. (2020) ICE-5G curve. The viscosity profiles that minimized the Hallmann et al. (2018) data-model misfit are: (1) for BM2016: lithosphere thickness (LT) of $120 \mathrm{~km}$, upper mantle viscosity (UMV) of $10^{21} \mathrm{~Pa}$.s and a lower mantle viscosity (LMV) of $3 \times 10^{21} \mathrm{~Pa}$.s; and (2) for ICE-5G: LT $=71 \mathrm{~km}$, UMV $=0.5$ $\times 10^{20} \mathrm{~Pa} . \mathrm{s}$ and $\mathrm{LMV}=3 \times 10^{21} \mathrm{~Pa}$.s. In contrast, Rashid et al. (2014) used the viscosity profile for ICE-5: LT $=100 \mathrm{~km}, \mathrm{UMV}=5 \times 10^{20} \mathrm{~Pa} . \mathrm{s}$ and $\mathrm{LMV}=5 \times 10^{21}$ Pa.s. (B) Comparison of glacio-eustatic sea-level change estimates. Glacio-eustatic sea-level changes (changes in ice volume only) as represented in BM2016 (Bradley et al., 2016 in black) and ICE-5G (Peltier, 2004 in gray). Observations (black and gray squares) corrected for GIA based on the best-fitting model (in black: BM2016; LT = $120 \mathrm{~km}$; UMV = $10^{21}$ Pa.s; LMV = $3 \times 10^{21}$ Pa.s; in gray: ICE-5G; LT = 71 km; UMV $=0.5 \times 10^{21}$ Pa.s; LMV $=3 \times 10^{21}$ Pa.s). Glacio-eustatic history inferred by Lambeck et al. (2014) is shown in blue. This figure has been published in Hallmann et al. (2018).

The sea-level curve published by Rashid et al. (2014) has been challenged recently by the reconstruction of mid- to lateHolocene RSL changes based on high-precision GPS positioning and precise U/Th dating of 78 samples of in situ coral microatolls from five French Polynesian islands (Hallmann et al., 2018)unfortunately not quoted in Rashid et al. (2020), then extended to 91 samples of in situ coral microatolls (Hallmann et al., 2020). This sea-level dataset is therefore robust enough both to reconstruct the evolution of MLWS through time and to track regional sea-level trends and climatic oscillations on interannual to millennial time scales. This RSL curve is shown in Figure 1 below and compared to model outputs based on BM2016 and ICE-5G ice models to illustrate the contribution of GIA to the temporal variability of sea-level changes at the millennial scale (see details in Hallmann et al., 2018). The relevant RSL curve documents a short-lived, $\sim 700$ years, sea-level highstand of less than a meter between 4.10 and $3.40 \mathrm{kyr}$ BP, following an overall sea-level rise from 6.0 to $4.10 \mathrm{kyr} \mathrm{BP}$ and preceding a fall in sea level between 3.40 and 1.26 kyr BP (Hallmann et al., 2018, 2020). The vast majority of our coral microatoll data-typifying the MLWS - plot significantly below (up to $1.3 \mathrm{~m}$ ) the former sealevel data published by Rashid et al. (2014) and considered in Rashid et al. (2020).

Rashid et al. (2020) aims at demonstrating that cyclic SST variations may superimpose GIA-controlled sea-level height

\section{REFERENCES}

Bradley, S. L., Milne, G. A., Horton, B. P., and Zong, Y. (2016). Modelling sea level data from China and Malay-Thailand to estimate Holocene ice-volume equivalent sea level change. Quat. Sci. Rev. 137, 54-68. doi: 10.1016/j.quascirev.2016.02.002

Camoin, G. F., and Webster, J. M. (2015). Coral reef response to quaternary sea-level and environmental changes: state of the science. Sedimentology 62, 401-428. doi: 10.1111/sed.12184

Hallmann, N., Camoin, G., Eisenhauer, A., Botella, A., Milne, G. A., Vella, C., et al. (2018). Ice volume and climate changes from a 6000-year sea-level record in French Polynesia. Nat. Commun. 9:285. doi: 10.1038/s41467-017-02695-7

Hallmann, N., Camoin, G., Eisenhauer, A., Samankassou, E., Vella, C., Botella, A., et al. (2020). Reef response to sea-level and environmental changes in the Central South Pacific over the past 6,000 years. Glob. Planet. Change 195:103357. doi: 10.1016/j.gloplacha.2020.103357

Lambeck, K., Rouby, H., Purcell, A., Sun, Y., and Sambridge, M. (2014). Sea level and global ice volumes from the Last Glacial Maximum to the Holocene. Proc. Natl. Acad. Sci. U.S.A. 111, 15296-15303. doi: 10.1073/pnas.1411762111

Peltier, W. R. (2004). Global glacial isostasy and the surface of the ice-age Earth: the ICE-5G (VM2) model and GRACE. Ann. Rev. Earth Planet. Sci. 32, 111-149. doi: 10.1146/annurev.earth.32.082503.144359 based on sea-level data published by Rashid et al. (2014). The authors especially estimate that during the defined "warm" intervals (1.8-2.8 and 3.7-4 ka), empirical sea-level estimates are on average about $0.4 \mathrm{~m}$ higher than the sea level corrected from GIA processes and therefore deduce sea-level change caused by SST variations. The identification and quantification of such relationships must rely on an accurate reconstruction of RSL changes at high resolution. However, as mentioned above, the dated corals reported by Rashid et al. (2020) seemingly typify diverse palaeoenvironments and palaeowater depths and cannot be therefore regarded as accurate sea-level indicators. Furthermore, direct relationships between sea-level changes and SST variations can be hardly identified in Figure 10 from Rashid et al. (2020), due to the relatively large scattering of sea-level estimates.

Figure 1A displays the Hallmann et al. $(2018,2020)$ dataset (in color) overlying the data and interpretation presented by Rashid et al. (2020). This comparison implies that no direct relationship between the SST variations and sea-level changes can be identified in the relevant time window.

\section{AUTHOR CONTRIBUTIONS}

GC and $\mathrm{NH}$ wrote the article and conceived the figure. $\mathrm{NH}$ designed the figure.

Rashid, R., Eisenhauer, A., Liebetrau, V., Fietzke, J., Böhm, F., Wall, M., et al. (2020). Early diagenetic imprint on temperature proxies in holocene corals: a case study from french polynesia. Front. Earth Sci. 8:301. doi: 10.3389/feart.2020.0 0301

Rashid, R., Eisenhauer, A., Stocchi, P., Liebetrau, V., Fietzke, J., Rüggeberg, A., et al. (2014). Constraining mid to late Holocene relative sea-level change in the southern equatorial Pacific Ocean relative to the Society Islands, French Polynesia. Geochem. Geophys. Geosyst. 15, 2601-2615. doi: 10.1002/2014GC00 5272

Conflict of Interest: The authors declare that the research was conducted in the absence of any commercial or financial relationships that could be construed as a potential conflict of interest.

Copyright (๑) 2021 Camoin and Hallmann. This is an open-access article distributed under the terms of the Creative Commons Attribution License (CC BY). The use, distribution or reproduction in other forums is permitted, provided the original author(s) and the copyright owner(s) are credited and that the original publication in this journal is cited, in accordance with accepted academic practice. No use, distribution or reproduction is permitted which does not comply with these terms. 